\title{
Gizarte-zerbitzuak eta gizarte-langintza: zein da zein?
}

\author{
Nerea Zubillaga-Herran ${ }^{1}$ \\ Lan Harreman eta Gizarte Langintza Fakultatea, \\ Euskal Herriko Unibertsitatea (UPV/EHU) \\ nerea.zubillaga@ehu.eus
}

\author{
Ainhoa Berasaluze \\ Lan Harreman eta Gizarte Langintza Fakultatea, \\ Euskal Herriko Unibertsitatea (UPV/EHU) \\ ainhoa.berasaluze@ehu.eus
}

Gizarte-zerbitzuak eta gizarte-langintza sarri nahasten dira, bata zein bestea era berdintsuan erabiliz eta ulertuz, biek ala biek gauza anitz partekatzen dituztelako; besteak beste, hemen identifikatutako triangelu korapilatsua. Gizarte zerbitzuen sistemaren krisiari buruz mintzo garen honetan, haren jasangarritasuna bermatzeko bidean, sistema horren garapena eta sendotzea oztopatzen edo zailtzen duten elementu korapilatsuak identifikatu eta aztertu nahi izan ditugu. Objektuaren definizio eza, unibertsaltasunaren bidean egindako garapen urria, eta arreta- eta esku-hartze eredua: horiek dira triangelu korapilatsu horren hiru osagaiak. Gizarte-zerbitzuek eta gizartelangintzak elementu horiek partekatzen dituzte, eta bakoitzaren espezifikotasunetik abiatuz egin dugu hausnarketa, Gizarte Zerbitzuen Euskal Sistemaren sendotzea helburu harturik betiere. Berrikuspen bibliografikoaren bidez, elementu horietako bakoitza deskribatu dugu lehenik eta behin, hurrengo ataletan bi eratara aztertu ahal izateko: aurrena, gizarte zerbitzuen ikuspegitik, eta, hurrena, gizartelangintzarenetik. Ondorioei erreparatuz, ikusi dugu korapiloak partekatzea bien arteko nahasmenaren erroan egon daitekeela, eta bata zein bestea askatzea ezinbestekoa dela sistema sendotzeko.

\section{GAKO-HITZAK:}

Gizarte-zerbitzuak, gizarte-langintza, objektu zientifikoa, unibertsaltasuna, arreta-eredua, eskuhartze eredua.
Los servicios sociales y el trabajo social se mezclan a menudo, utilizando y comprendiendo uno y otro de forma similar, porque ambos comparten muchas cosas, entre otras, el complicado triángulo aquí identificado. Ahora que hablamos de la crisis del sistema de servicios sociales, en el camino de garantizar su sostenibilidad, hemos querido identificar y analizar elementos clave que obstaculizan o dificultan su desarrollo y consolidación. El complicado triángulo está formado por la indefinición del objeto, el escaso desarrollo en el camino de la universalidad y el modelo de atención e intervención. Los servicios sociales y el trabajo social comparten estos elementos y la reflexión se ha llevado a cabo desde la especificidad de cada uno de ellos, siendo el objetivo la consolidación del Sistema Vasco de Servicios Sociales. A partir de la revisión bibliográfica, en primer lugar, hemos descrito cada uno de estos elementos, para poder analizarlos en los siguientes apartados, primero desde el punto de vista de los servicios sociales y después, desde el del trabajo social. Atendiendo al análisis realizado, se concluye que compartir los nudos puede estar en la raíz de la confusión entre ambos y que la liberación de aquellos, uno y otro, puede ser el camino para la consolidación del sistema.

\section{PALABRAS ClaVE:}

Servicios sociales, trabajo social, objeto científico, universalidad, modelo de atención, modelo de intervención. 


\section{Sarrera}

“Objektua ondo definitua ez izateak umezurtz uztea dakarrenez, berebiziko garrantzia du objektua behar bezala definitzeak"; “marjinalitatearekin lotzen bada, hori horrela da asistentzia sozial gisa jaio zenak ez duelako egin gizarteko kolektibo zehatz eta ahulenetatik abiatuta gizarte osoarekin lan egiteko bidea"; "burokratizazioarekin eta, batez ere, asistentzialismoarekin lotzen da; izan ere, haren jatorri asistentzialaren arrastoak bizirik dirau, eta, horren ondorioz, baliabide-eskaera binomioaren mende dagoelarik, ezin dio ihes egin kutsu asistentzial eta paternalistari”: tankera horretako esaldiak sarri entzun edo irakurtzen ditugu, baina nola jakin zeri egiten dioten erreferentzia? Gizartezerbitzuei edo gizarte-langintzari? Galdera horixe da, hain zuzen ere, artikuluaren abiapuntua.

Sistemaren eta diziplinaren inguruan aurkitu ditzakegun elementu horiek batari zein besteari egokitu diezazkiokegunez, bien arteko nahasmenaren isla izan daitezke. Gizarte-langintza eta gizarte-zerbitzuen arteko talka aski ezaguna da, eta gure aburuz, ez dio inongo mesederik egiten gure testuinguruan ongizatea eta justizia soziala lortzeko egin daitekeen edozein esfortzuri, ez eta gizarte-zerbitzuen sistema publikoa garatzeko eta sendotzeko prozesuari ere. Badirudi gizartezerbitzuak direla gizarte-langintzaren jardute eremu-bakarra eta gizarte-langileak direla gizartezerbitzuetan dauden profesional bakarrak; hori dela eta, bien arteko nahasmena handia da eta horrek baditu bere eraginak: batetik, gizarte-langintza baliabideen kudeaketaren funtzio asistentzial eta burokratikora mugatzen da, baliabide-eskaera binomiora; bestetik, gizarte- zerbitzuei erreparatuz, prebentiboagoak eta komunitarioagoak diren beste sektore eta esku-hartzeen ikusezintasuna sustatzen du. Eta noski, anabasa horrek sistemaren eta diziplina-lanbidearen identitateari eragiten dio, bakoitzaren espezifikotasunak ahazteraino.

Gizarte-langintzaren eremuan, asko gara gizartezerbitzuen sistemen inguruan lan egiten dugunok, dela gizarte-zerbitzuetako gizarte-langileak garelako, dela eremu akademikotik sistema eta haren testuingurua ikertzen aritzen garelako. Hori horrela, badira urte batzuk gizarte-zerbitzuen mugen inguruan mintzo garela, eredua agortu delako, sistemak berak dituen helburuak betetzeko ezintasuna dagoelako edo sistemaren legezko esparrua errealitatetik urruti geratzen delako.

2008ko krisiaz geroztik, argi ikusi dugu sistemak pobrezia- eta bazterketa egoerei aurre egiteko zailtasunak dituela, egiten diren esku-hartzeek berek ere mugak dituztelako ziur asko, gizarte-zerbitzuen alorreko esku-hartzeen ahalak erraz ahantz edo desagerraraz baitaitezke. Honenbestez, egungo ongizate-ereduaren jasangarritasuna ez dago ziurtatua. Sistemaren iraunkortasuna oztopatzen duten eta aurrez jada existitzen ziren mugak berretsi besterik ez du egiten COVID-19aren eraginez bizitzen ari garen krisiak, eta egoera are konplexuagoa bihurtu du. Zamanillo eta Noguések (2020) aipatzen dutenez, gizarte-zerbitzuak bidegurutze batean aurkitzen dira, eta haien jasangarritasuna bermatu nahi bada, aldaketak egin beharko dira, argi geratu baita, ez daudela egungo beharrizan eta konplexutasunei aurre egiteko prestatuta. Horrela, ezintasunaren aurrean, aldaketaren beharra azpimarratu nahiko genuke.

Gizarte-langintzak, bere aspektu instrumental eta teorikoetan, ekarpen handiak egin dizkio gizartezerbitzuen sistemari, baina, era berean, aipatzekoa da gizarte-zerbitzuek ahalbidetu dutela gizartelangintzaren garapen profesionala. Gure kasuan, aurreko guztiarekin bat eginez, gizarte-ongizatea, kohesio zein justizia soziala bermatzeko erreminta garrantzitsutzat jotzen dugu Gizarte Zerbitzuen Euskal Sistema, eta haren egungo egoerari aurre nola egin eta hura nola eraldatu hausnartu gurako genuke, eta, gu geu gizarte-langileak izanik, aitortuko dugu hori gure diziplinaren ikuspegitik egingo dugula.

Bien arteko talka horren aurrean, gure helburua zera izan da: biak ere, izenburuan jasotzen den bezala, ezberdinak direla onartuz eta bakoitzaren espezifikotasuna aintzat hartuz aztertzea bai gizarte-zerbitzuak eta bai gizarte-langintza, eta ezberdintasun horiek aukeratzat hartzea. Horrela, Gizarte Zerbitzuen Euskal Sistemaren jasangarritasuna bermatze aldera gogoeta egingo dugu nahasmena eragiten duten eta sistemaren, diziplinaren eta lanbidearen garapena eta sendotzea mugatzen duten elementuei buruz.

Hausnarketa hori egiteko, bibliografia berrikusi dugu eta gizarte-zerbitzuek eta gizarte-langintzak partekatzen dituzten eta bataren zein bestearen garapena eta sendotzea oztopatzen duten zenbait elementu identifikatu ditugu, elementu korapilatsu gisa izendatu ditugunak. Hasierako atalean, elementu horietako bakoitza azaldu, eta gizarte-zerbitzuentzat eta gizarte-langintzarentzat zergatik diren garrantzitsu adieraziko dugu. Hori egin ondoren, elementu korapilatsu bakoitza aztertuko dugu: hirugarren atalean, gizartezerbitzuen ikuspuntutik, eta, laugarrenean, gizartelangintzarenetik. Azken atalean, gure hausnarketatik ateratako ondorioak jaso, eta Gizarte Zerbitzuen Euskal Sistema sendotze aldera sortutako ideiak partekatuko ditugu.

\section{Elementu korapilatsuen nondik norakoak: objektua, unibertsaltasuna eta eredua}

Gizarte Zerbitzuen Euskal Sistema indartzeko bidean, gizarte-langintza eta gizarte-zerbitzuen bueltan aurkitu daitekeen produkzioaren berrikuspena egitean, biek partekatzen dituzten eta elkarreraginean dauden hainbat elementu identifikatu ditugu, elementu korapilatsu gisa izendatu ditugunak. Sarreran aipatu 
bezala, gizarte-langintza, zeina diziplina akademiko zein lanbide izan baitaiteke, eta gizarte-zerbitzuak nahastu egiten dira sarri, batez ere gizarte-langintzak duen lanbide-izaeragatik eta gizarte-langileek gizartezerbitzuetan duten pisuagatik. Elementu korapilatsu horiek, baina, bientzat izan arren garrantzitsuak, bakoitzari era ezberdinean eragiten diote; horregatik, bakoitzaren espezifikotasunak aztertzen hasi baino lehen, elementuok definituko ditugu, zertaz ari garen jakiteko.

Gizarte-zientzien eta gizarte-langintzaren objektua da identifikatu dugun lehenengo elementu korapilatsua. Hiztegien arabera, zientzia batek ezagutzea edo eraldatzea helburu duen materia edo gaia da objektua. Erabilera, ordea, testuinguru askotan gauzatzen da: ezagutzaren alorrean ez ezik, baita praktikarenean edo ekintzarenean ere. Gehientsuenetan, dena den, objektua errealitate fisikotik bereizten den eraikuntza zientifiko abstraktua izan ohi da, eta ez da beraz, zentzumenek hauteman dezaketen hori, baizik eta objektu sentikorraz harago dagoen eraikuntza teorikoa. Hala ere, praktika produktibo, profesional edo sozial batetik abiatuz eraikitzen denaren kategoriari erreferentzia egiteko ere erabiltzen da, lanbide edo subjektu batek objektuaren gainean eraikitzen baitu bere identitatea. Finean, objektua diziplina edo sistema bati berariaz dagokion errealitatearen zati bat legez uler dezakegu, diziplinari ezagutza materia sortuz eta sistemari berriz, ekintza edo interes esparrua.

Gizarte-zerbitzuetan, objektuak sistemaren beraren mugak eraikitzen dituela esan dezakegu, edo, beste era batera esanda, autore askok dioten bezala, bere ekintza-eremua zehazten duela (Aguilar Hendrickson, 2014). Gizarte-langintzan, berriz, diziplinari edo, hala dagokionean, lanbideari espezifikotasuna ematen diona da, hau da, beste diziplinetatik edo lanbideetatik bereizten duena (Zamanillo, 1999).

Bigarren elementu korapilatsua, eta, hasieran aipatu bezala, aurrekoarekin oso lotuta dagoena, unibertsaltasuna da. Unibertsaltasunaz asko hitz egin izan da azken urteetan, gizarte-zerbitzuen sistemek beren barnean hartzen duten printzipio nagusietako bat baita. Horretaz gain, gizartelangintzaren kasuan ere badu bere garrantzia, arestian txiroei eta gizarte-bazterketa egoeran dauden pertsonei laguntzeko lanbidea zen hura eraldatu egin baitzen, eta, harrezkero, gizartekohesioa sustatzea eta justizia soziala erdiestea helburu dituen diziplina eta lanbide izatera iristeko bidea markatu baitu. Hiztegien arabera, unibertsal hitzak orokorra, guztiekikoa adierazten du, eta lan honetan ere horrelaxe ulertzen dugu.

Azken elementu korapilatsua, eredua, aurreko biei estuki lotuta dago, eta bi alor hartzen ditu barnean: arreta-eredua, gizarte-zerbitzuei dagokienez; eta esku-hartze eredua, gizarte-langintzari dagokionez. Viscarretek (2009) aipatzen duenez bizitza akademiko eta profesionalean maiz erabiltzen den kontzeptua da, ezinbestekoa baita gertakariak, fenomenoak eta egoerak deskribatu, ulertu, azaldu eta aurreikusteko. Horri zera gaineratzen dio: ikuspuntu epistemologikotik errealitatearen deskribapen edo irudikapenaren itxurako zerbait dela (gertaerak, egoerak, fenomenoak, prozesuak, egiturak eta sistemak, besteak beste), eta, oro har, teoria baten suposizio teorikoen araberakoa dela. Ondorioz, batetik, idealizazioa eta abstrakzioa adierazten omen ditu, fenomeno bat edo sistema bat hezurmamitzeko beharrezkoak diren baldintza perfektuak adierazten dituelako, eta, bestetik, ikerketa- edo ekintza-eremu jakin baten hurbilpen eskematizatua omen da, errealitatearen aspektu edo aldagai esanguratsuenak azaltzen dituelako, hura bere osotasunean azaldu beharrean. Aurreko esanahiak ikusita, esan daiteke garrantzi handiko elementua dela bai gizarte-zerbitzuen sistemarentzat eta bai gizartelangintzarentzat. Beraz, sistemaren markoak haren ezaugarriak markatzen eta sistemaren beraren eta diziplinaren printzipioak adierazten ditu; hots, ekiteko modua zuzentzen, gidatzen eta adierazten du.

1. irudia. Triangelu korapilatsua

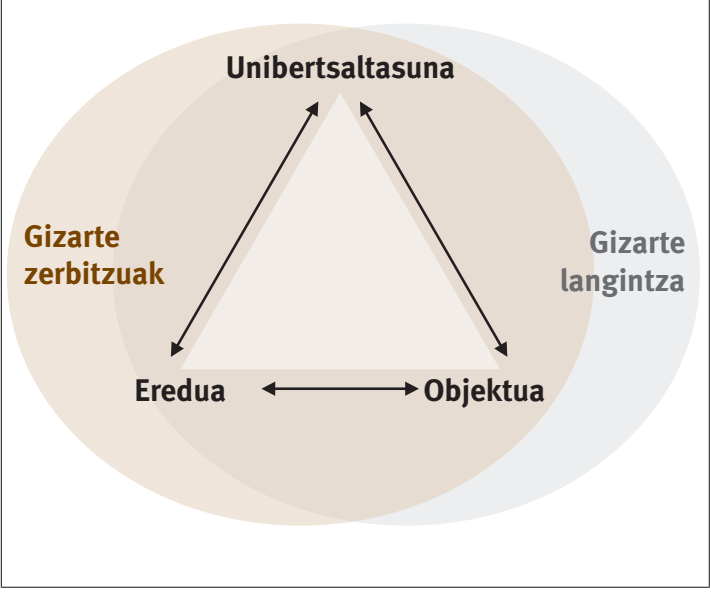

Iturria: Egileek egina.

Elementu korapilatsu bakoitzari buruz zer ulertzen dugun argitu ondoren, haien arteko elkarreragina nabarmentzeko, triangelu korapilatsu bat osatuko dugu, zeharka eragiten diena bai gizarte-zerbitzuen sistemari eta bai gizarte-langintzari ere -diziplinari nahiz lanbideari-. Objektuak sistema bera zein diziplina definitzen dituela esan dezakegu, ekintzaeremua marrazten baitu: alegia, zertan zentratu beharra daukagun, zertan eragin behar dugun, gure misioa zein den, eta, finean, zer eraldatu nahi dugun, zer dagokigun eta zer ez adierazten du. Hori dela eta, unibertsaltasunak sekulako zeresana izan du azken hamarkadetan, modua eman baitigu diziplinaren eta sistemaren ekintza-eremua -objektuak berak definitutako eremua, alegia- hedatzeko. Bi horiek uztartze aldera, ereduak finkatu behar izan dira, batean zein bestean aldatuz joan direnak; hala, gaur egun, era askotako ereduekin egiten dugu topo -ereduok, maiz, jarduera profesionalak izaten dira-, eta, horren ondorioz, muga handiak aurkitu ohi dira 
sistemak ezarritako ereduekin bat egiteko. Hortaz, esan daiteke korapilatsu gisa identifikatu ditugun elementuen arteko elkarreragina begi-bistakoa dela, eta halaxe osatzen dela hemen ikusgai dagoen triangelu korapilatsua.

Hurrengo lerroetan, beraz, elementu korapilatsu horiek azaltzen saiatuko gara, gizarte-zerbitzuetatik eta gizarte-langintzatik abiatuta, korapiloa askatzeko erabilgarriak izan daitezkeen ekarpenak berreskuratzeko eta aintzat hartzeko asmoz.

\section{Korapiloak gizarte-zerbitzuetatik abiatuta aztertzen}

Egun, gizarte-zerbitzuen krisialdiaz hitz egiten hasiak gara, sistemak egun duen antolaketa dela-eta eguneroko errealitateari erantzuten ote dion, hari erantzuteko gaitasunik ba ote duen, etab. Kontuak kontu, dena den, onartu beharra dago hura dela pertsonaren eta talde edo komunitateen alderdi soziala aintzat hartuz lan egiten duen babes-sistema bakarra, eta, alde horretatik, beharrezkoa da haren balioa eta garrantzia azpimarratzea.

Ongizate-estatuaren barruan kokatu izan dira orokorrean, II. Mundu Gerraren ostean sortuak baitira, baina, Espainiako estatuan, egoera politikoak baldintzaturik sortu eta garatu behar izan dira. Gizarte-zerbitzuetan eragiten duten korapiloak askatzeko, ezinbestekotzat jotzen dugu haien azterketa xumea egitea.

Hasteko, garrantzitsua da haren inguruan zer kontzeptualizazio egiten diren jakitea. Nahiz eta zailtasun handiak egon zerbitzuok definitzeko, oro har esan genezake ardura publikoko zerbitzuen sarea dela, edo, are gehiago zehaztuz, hibrido bat dela, antzinako ongintza edo gizarte-laguntza atzean utzi eta ongizate-estatuaren sektore nagusi edo zutarri bihurtzerainoko eraldaketa-prozesuan aurrera egin nahi duena (Aguilar Hendrickson, 2014). Hurrengo definizio hau posible guztien arteko bat besterik ez da, baina aurrez aipatutakoak baino zehatzagoa da:

Gabeziak estaltzeko eta potentzialtasunak garatzeko, autonomia (edo mendekotasun) pertsonalarekin eta integrazio (edo bazterketa) orokor eta komunitarioari lotuta, laguntza eta babesa eskaintzen duten prestazio tekniko eta jarduerak, batez ere erlazionalak eta hurbiltasunezkoak. (Fantova, 2008: 35. or)

Lehenengo elementu korapilatsua aztertzen hasi eta, gizarte-zerbitzuen objektuaren definizio faltari dagokionez, alor horretan ikertzen edo jarduera profesional horretan lanean ari direnak bat datoz: objektua ondo definitua ez izateak arazoak dakartza, eta gizarte-zerbitzuen jarduna eta ekintza-eremua bera ere umezurtz uzten ditu, horren gainean eraikitzen baita beste guztia, baita sistemari berari forma eta zentzua ematen dizkioten zimenduak ere.
Gizarte-zerbitzuen legeak aztertuz gero, jabetzen gara gizarte-zerbitzuen sistema ordenatzea eta egituratzea har litekeela objektutzat, bai eta zerbitzuokin lotutako sistema publikorako eskubidea sustatzea eta bermatzea ere, eta objektu horrek helburu hauek lotzeko balioko lukeela: pertsonek beren bizitza era librean gobernatzeko eta garatzeko behar dituzten baliabide eta zerbitzuak haien eskura jartzeko; bazterketaren kausak desagerrarazteko edo aurrea hartzeko; gizarte-partaidetza eta elkartasuna sustatzeko, horrek pertsona guztien inklusioa bermatu eta gizarte-zerbitzuen kudeaketa koordinatzen lagundu dezan (Fernández García, De Lorenzo eta Vázquez, 2012). Hala ere, ikusitakoak ikusi ondoren, ezin esan objektuaren zehaztasunak duen garrantziaren mailan dagoenik hari buruz aipatutako definizioa, egoera zehaztu ez baizik eta deskribatu egiten baitu.

Gizarte-zerbitzuen sistemaren zailtasun nagusi gisa identifikatu dezakegu objektuaren mugaketarik eza eta haren inguruko nahasmena, eta, hala eta guztiz ere, argi esan behar da mugaketa hori beharrezkoa dela sistema garatzeko eta ongizatea bermatzeko (Aguilar Hendrickson, 2014). Ildo horretan, Santosek (2012) aipatzen duenez, objektu definiturik gabe zaila da sistema garatu, egonkortu eta hura ongizateestatuaren laugarren zutabe bilakatzea.

Aguilar Hendricksonek (2014) zentzu zabalean hartu du objektua, hots, egin beharreko ekintzen multzo gisa, eta gizarte-ongizatea edo bizi-kalitatea ere erabili izan ditu haren parekotzat; egile horren esanetan, objektua gidalerro hauen arabera formula daiteke: mendekotasun-egoeran egon litezkeen pertsonen zaintza ziurtatzea eta prebentzio-lana egitea, halako egoerak gutxiago izan daitezen; adingabeak zaintzea, haien gurasoak ezin badira horretaz arduratu; haur eta gazteek beren guraso edo tutoreengandik arreta egokia jasotzen dutela bermatzea, eta, azkenik, oztopoak edo zailtasunak dituzten pertsonen bidelagun izatea, haien erabateko garapena eta komunitate-inklusioa ziurtatzeko. Autore berak (2018), aurrez aipatutakoak zehaztu eta zertxobait hedatu, eta eginbeharrak ere zerrendatzen ditu; adibidez: gurasoen arreta jaso ezin dezaketen haurrak edo mendekotasunegoeran dauden pertsonak zaintzea eta babestea; edozein gizarte-politikaren inguruko informazioa eta aholkularitza eskaintzea; jendearekin lan egitea, krisialdirik edo zailtasun sozialik bada; herritarren garapen pertsonala eta sozializazioa sustatzea, eta autolaguntza-ekimenak eta ekimen komunitarioak bultzatzea.

Fantovak, berriz, askoz ere modu hertsi eta konkretuagoan egiten du bere proposamena, eta zera esaten du: osasun-zerbitzuen objektua osasuna, etxebizitza-zerbitzuena etxebizitza eta hezkuntza-zerbitzuena ikasketak edo jakintza diren bezala, gizarte-zerbitzuek ere objektu jakin bat izan beharko luketela. Horrela, elkarrekintza proposatzen du: autonomia funtzionalaren eta integrazio erlazionalaren bidezko elkarrekintza, 
hain zuzen ere. Pertsonak lan-eremura edo osasuneremura jo dezakeen bezala, eremu komunitariora ere jo ahal izan beharko luke, oinarrizko harremanen eremu den aldetik. Fantovak txanpon beraren bi aurpegitzat jotzen ditu autonomia funtzionala eta integrazio erlazionala: egunerokotasunean geure kabuz zer egiteko gai garen adierazten du lehenengoak, baina egileak gogorarazten digu bizitza komunitarioan harremanak ditugula elkarrekin, eta, beraz, interdependenteak garela -horregatik darabil autonomia hitza, eta ez independente hitza-; bigarrenak, aldiz, oinarrizko harreman horietan dauden babes- eta lotura-alderdietan jartzen du arreta, eta halakoetan pertsonek zer-nolako gaitasunak dituzten eta zer egin dezaketen hartzen du aintzat. Horiek horrela, elkarrekintza izan liteke, egilearen esanetan, gizarte-zerbitzuen objektua egokien definitzen duena:

Pertsonen elkarrekintzarekin lotutako desorekak prebenitzea, zuzentzea edo arintzea helburu duten jarduerak, haien bi alderdi edo dimentsioekin; batetik, eguneroko bizitzarako autonomia funtzionala; eta, bestetik, bestetik, harreman-integrazioa (familiakoa eta, oro har, komunitatekoa). Lehenik, eguneroko bizitzako autonomia funtzionaltzat jotzekoak dira zaintza eta autozaintza, egunerokotasuneko oinarrizko jarduerak, jarduera instrumentalak eta jarduera aurreratuak, norberaren bizitzari eta etorkizunari buruzko erabakiak hartzeko funtzio kognitibo eta emozionalak erabili beharra dakartenak (autodeterminazioa, autoantolaketa eta autogobernua), eguneroko bizikidetzarako trebetasun sozialak ere barne direla. Eta, bigarrenik, integrazio erlazionala estu lotuta dago familia-harremanekin eta beste sare komunitario presentzial edo birtualekin, bai unean unekoekin eta bai balizkoekin (eta den-denak dira lehen mailako harremanak), gizarte-laguntzako funtsezko iturri diren aldetik. (Fantova, 2019: 7. or.)

Objektua horrela mugatzearen ondorioz, ongizatea bere hartan objektu gisa ez hartzea lortzen da;izan ere, ongizatea faktore askoren araberakoa da -enplegua, etxebizitza, osasuna, hezkuntza...-, eta faktore horiek denak ez dira gizarte-zerbitzuen alorrekoak. Hori dela eta, autorearen ustez, elkarrekintza sustatzea eta babestea zeregin garrantzitsua izan daiteke, beste alor batzuekiko sinergiak lortuz egin daitekeena, eta gizartezerbitzuei euskarri sendoa eskain diezaieke, haiek garatzearen eta indartzearen aldeko estrategia bat sortzearen bidez.

Bigarren elementu korapilatsuari erreparatzen badiogu, aurrekoarekin duen loturaz ohartuko gara; izan ere, unibertsaltasun zeri esaten zaion edo izen horrekin praktikan zer egiten den, objektua aldatu egin daiteke. Unibertsaltasuna gizarte-zerbitzuen antolakuntza-printzipio operatiboetako bat da, eta, haren arabera, zerbitzu horiek guztionak eta guztiontzat dira. Hori horrela, bazterketaegoeran edo gizarte-maila ahulenetan dauden pertsonei prestazioak eskaintzen dizkien zerbitzu asistentzialetatik harago, herritar guztiek izan beharko lukete, herritar izate hutsagatik, gizartezerbitzuetara jotzeko aukera, eta horrek ikuskera asistentziala gainditzea ekarriko luke.

Aguilar Hendricksonen (2018) esanetan, antzina ere, Europan, auzioi buruz mintzo ziren autoreek ongizate-estatuaren seigarren zutabetzat jotzen zituzten gizarte-zerbitzuak, osasunarekin, hezkuntzarekin, etxebizitzarekin, diru-sarreren bermearekin eta lanerako formakuntza-politikekin batera, eta haien unibertsaltasuna sakontzea zen xedea. Ideia horrek, baina, zera dakar: haureskolak, gurasoentzako aholkularitza-zerbitzuak, udako aisialdi-zerbitzuak, zentro komunitarioak eta horien kidekoak gizarte-zerbitzuen partetzat hartzea. Ikuspegi horri jarraituz, gizarte-zerbitzuak pobreentzat soilik direlako ideia gainditzen dute autoreek, eta, zailtasunak dituzten pertsonez gain -haurrak eta mendekotasun-egoeran dauden pertsonak, besteak beste-, bestelako egoera ekonomikoa dutenak ere jotzen dira gizartezerbitzuetako. Europako Batzordeak gizartezerbitzuen gainean 2006an eginiko txostenean ere jasotzen dira haurtzaroarekin lotutako zaintzaprogramak, etxebizitza sozialei buruzko programak eta kidekoak. Hortxe ager liteke, hain zuzen, unibertsaltasuna lortzeko beste oztopo bat (Huber, Maucher eta Sak, 2006). Etxebizitzaren inguruan, esaterako, gurean politika propioak ditugun arren, egiaz ba al dute eraginkortasunik? Etxebizitza sozialak etxebizitza-politiken barruan kudeatzen dira, baina pertsonek horra iristeko adina diru-sarrera ez badute, gizarte-zerbitzuen alojamenduetara edo bizitokietara jotzen dute. Unibertsaltasuna bermatze aldera, beraz, Aguilar Hendricksonek lau esparru proposatzen ditu: lehenik, asistentzia soziala esaten diona, pertsonen oinarrizko beharrizanak asetzea helburu duena, hots, egoera ekonomiko okerrenean dauden pertsonekin lan egitea; gero, ordea, egoera ekonomikoarekin zerikusirik ez duten beste hiru esparru aipatzen ditu autoreak: haur-garapena eta gurasotasuna, iraupen luzeko zaintzak, eta, amaitzeko, integrazioa.

Europako gainerako herrialdeen aldean, Espainiako estatuan atzerapenarekin sortu ziren gizartezerbitzuak, eta, aurreko egitura frankisten eta Elizaren eraginez, ongintzaren logika eta logika asistentzialistak nagusitu ziren ezinbestean, eta, gaur egun ere, antzematen dira horren zantzuak (Hernández-Echegaray, 2019). Bestalde, badirudi areagotu egin dela eduki espezifikorik gabeko azken buruko laguntza- edo babes-sare gisa gizarte-zerbitzuek duten nortasuna, eta horren arabera funtzionatzen dutela, gainerako baliabide eta euskarriek huts egitean soilik jo beharko balitz bezala sare horretara. Izan ere, ia edozertarako jo daiteke zerbitzuotara -elikagaiak lortzeko; argia, botikak, arropa, betaurrekoak eta oinarrizko premiekin lotutako beste edozer gauza ordaintzeko; zaintza-lanetarako; ostatua eskuratzeko; harremanetarako; etxez etxeko zerbitzuetarako; 
lan-orientaziorako...-, baina soilik lortu nahi den hori lortzeko beste modurik ez dagoela frogatzen bada. Esan genezake indartzen ari dela estali gabeko larrialdi-egoerei ia esklusiboki erantzuteko sistemak duen izaera erresiduala. Horrek ez du laguntzen unibertsalizazio-prozesuan, gizarte-zerbitzuak pobreentzat direlako ideiak imajinario kolektiboan bere hartan jarraitzea sustatzen duelako.

Hala ere, gizarte-zerbitzuen hirugarren belaunaldiko legeek eskubide subjektiboa jasotzen dute eta, jakina, baita unibertsaltasuna ere. Zenbait eztabaida ere sortu dira, ordea, halakoak garatu ahala; esate baterako, diskrezionaltasunaren eta unibertsaltasunaren arteko talken gainean. Unibertsaltasuna ez dago lehian larrialdi-egoeren trataerarekin, ez behintzat osasun sistemari erreparatzen badiogu. Baliabide eta zerbitzuetara heltzeko irizpide komunak ezar daitezke, kasuaren prebentzio-aukeren, bazterketaren intentsitatearen, aukeren irizpidearen edo profilaren arabera, besteak beste (Martínez Virto eta Pérez Eransus, 2018).

Horretaz gain, estatuek hirugarren mailakotzat jotzen dituzte gizarte-politikak, gobernuek ez dituzte lehentasuntzat hartzen, eta horrek, besteak beste, finantzaketari eragiten dio. Adituek diotenez, gizarte-zerbitzuen finantzaketa beti izan da behar baino txikiagoa, urteen poderioz jaitsiz joan dena eskariak igo arren. Gizarte-zerbitzuak merkatzeko formulak artikulatzen dira; izan ere, iruditeria politikoan, gizarte-zerbitzuak inbertsio ez baizik eta gastu direlako ideia dago, eta, ondorioz, sistema prekarizatu egin da. Gainera, adituek adierazi dute politikan diru gehiago bideratzen dela kolektibo estrategikoetara (adinekoak) gainerakoetara baino baina, hala eta guztiz ere, gehiegitzat hartzen dute herritarrek pobrezian eta bazterketan egindako inbertsioa, gizarte-zerbitzuen "kolektibo izarra" delakoan (Hernández-Echegaray, 2019).

Unibertsaltasunaren printzipioa aurrera eramateko, ezinbestekotzat jotzen da aurrekontua igotzea (Aguilar Hendrickson, 2014), baina ez modu arbitrarioan, unean uneko egoera ekonomikoaren arabera, baizik eta unibertsaltasuna eskubide gisa aintzat hartuz. Horretarako, beraz, garrantzitsua da gizarte-zerbitzuak oinarrizko eskubidetzat hartzea, eta politika paternalistak eta asistentzialistak -hurrengo elementu korapilatsua, hain zuzen- gainditzea.

Honenbestez, gizarte-zerbitzu unibertsalak gura baditugu, zenbait pauso ematea ezinbestekoa da: lehenik, osasungintzan edo hezkuntzan gertatzen den legez, gizarte-zerbitzuen sare publikoak ere kalitateko alternatiba izan behar du, herritar guztiontzat irisgarri eta erakargarri;. bigarrenik, gizarte-zerbitzuak eskubide subjektibo gisa jaso behar dira legedian; hirugarrenik, politikoki ere behar besteko zentraltasuna eman behar zaie, eta, horretarako, batetik, teknikoki eta zientifikoki garatu behar dira ezagutzaren bidez, eta, bestetik, inbertsio ekonomiko sendoa egin behar da; eta, laugarrenik, errekonozimendu soziala beharrezkoa da sistemaren kontsolidaziorako eta gizarte-zerbitzuak ongizateestatuaren laugarren zutabetzat hartzeko, horretarako funtsezkoa baita jendearen ezagutza eta babesa.

Aurreko bi elementu korapilatsuak aztertzearekin batera, ikus dezakegu gaur egun legeak markatzen duenaren eta jarduera profesionalaren artean aldeak sor daitezkeela haien ondorioz, eta, alde horretatik, maiz zalantzan jarri izan da gizarte-zerbitzuak benetan diren ongizate-estatuaren laugarren zutabea edo gainerako sistemen erantzunik ezaren aurrean pertsonek aurkitzen duten azken baliabidea Jaraíz, 2011). Hausnarketa horrek zuzenean garamatza hirugarren elementura.

Hirugarren elementu korapilatsuari begiratuz gero, hura ere aurreko biekin estuki lotua dagoela ikus dezakegu, egun gizarte-zerbitzuetan nagusitzen den arreta-eredua aurreko bi elementuen gatibu baita. Era askotako arreta-ereduak daude, eta gure jarduera profesionala haietako zeinetan oinarritu beharko genukeen legean bertan esaten den arren, gizarte-zerbitzuen alorreko praktikak beste norabait eramaten gaitu gaur egun.

12/2008 Legeak arreta-eredu komunitarioa aldarrikatzen du, bai eta Pertsonarengan Zentratutako Arreta-eredua ere. Eredu horren arabera, pertsona bere testuinguruan eta ingurune sozialaren eraginpean baino uler ezin daitekeenez gero, faktore horiei erreparatuz eta pertsona erdigunean jarriz artatu behar dira gizonemakumeak. Eredu hori gero eta nabariagoa da adineko pertsonen eta mendekotasunaren esparruan (SIIS, 2019).

Objektua ongi definiturik bagenu, eta irmoki egingo bagenu unibertsaltasunaren alde, horrek eredua legera egokitzera behartuko gintuzke. Baina hori horrela izan ez denez, burokratizazioa hain nabarmen hazi ahala, horrek asistentzialismoaren eta eskaeren eredua erabat nagusitzea ekarri du.

Gaur egun, gizarte-zerbitzuen lana kutsu asistentzial eta paternalistari ihes egin ezinik dabil (Arenas, 2016), aski ezaguna den baliabide-eskaera binomioaren mende baitago erabat, gero eta burokratizatuago. Horrek ondorio saihetsezin bat dakar: esku-hartze sozialari eta zerbitzuok berezko duten akonpainamendu-funtzioari gero eta denbora gutxiago eskaintzeko joera, alegia. Eskaera artatu behar dela onartzen dugu, baina, gizarte-zerbitzuen egoera ezagututa, uste dugu behar handia dagoela lan estrategiko eta proaktiboaren alde egiteko. Ildo horretan, nabarmen geratu da helburu estrategikoak markatu behar direla, beharrei haien garrantziaren arabera erantzun behar zaiela eta herritarrek paper aktiboagoa izan behar dutela, batez ere lehen mailako arretan. Horretarako ezintasuna gizarte-zerbitzuen sistemak ustez duen "gabezia kognitiboari” egozten zaio, kontzeptualizazio urriarekin sortua izan balitz bezala. Hori horrela, 
eskaeraren arabera funtzionatzera beharturik daude gizarte-zerbitzuak, ahal duten moduan erantzutera. Eskariaren arabera funtzionatzen duen sistema eraginkorra da egoera larrien aurrean, baina ez egoera kronikoa, luzea edo beste era batekoa bada. Ondorioz, efikaziarik eta efizientziarik eza da halako eredu asistentzialisten patua. Badaude jada hori gainditzeko ereduak, egoeraren konplexutasunaren araberako erantzunak edo ekimenak proposatzen dituztenak (Uribe, 2019).

Egungo pandemiaren ondorioz, eskariaren araberako ereduak eta oinarrizko beharrizanei erantzun beharrak indartu egin dute baliabideen kudeatzaile-rol edo eredu asistentzialista. Gizarte-zerbitzuei balio erantsia ematen dieten berariazko baliabide eta zerbitzuen kaltetan, funtzio administratibo ez-eraginkorrek gora egin dute, eta, hori dela eta, alde handia dago gaur egungo gizarte-zerbitzuen eta garai batekoen artean. Azken buruko sare edo sistema erresidual bihurtzen duten ekintzen artean, hain zuzen, badaude zenbait esku-hartze zaintzarekin, babesarekin eta gizarte-zerbitzuei balio erantsia ematen dieten beste baliabide batzuekin lot daitezkeenak, eta halakoak artikulatuz gero, horrek sistema edukiz bete eta unibertsalizaziorantz eramango luke. Bizitzen ari garen krisialdiaren ondorioz, ordea, ekintza horiek guztiak murriztu egin dira, eta azken buruko sarea elikatzen duten muturreko larrialdiegoerak eta larrialdi-egoera kronifikatuak, berriz, ugaritu. Hori horrela izanik, gizarte zerbitzuak, kutsu asistentzialistatik ihes egiteko orain dela urtebete baino urrutiago daude, asistentzialismoak (beste batzuk egin beharko luketena, haiek baino okerrago egitea bezala ulertuz) izugarri egin baitu aurrera. Ematen du asistentzialismoa halabeharrez dela gizarte-zerbitzuen izaeraren parte, eta ez garela hura ezabatzeko gai (Fantova, 2021).

Egia da aspaldian jasaten ari garen krisi-egoerak gizarte-zerbitzuetako baliabideen eskaria areagotu duela baina, aldi berean, profesionalek gestioari eskaintzen dioten denbora ere hazi egin da, eta burokratizazioa handitu. Gizarte-zerbitzuetako profesionalek esku-hartze sozialean jardun beharko lukete, baina maiz ez dago horretarako espaziorik. Martínez Virtok eta Pérez Eransusek (2018) diotenez, baliabideen gestioa aukera egokia izan daiteke eskuhartze prozesuak abiarazteko, baina horretarako oztopoak ere badaude: burokratizazioa hazi izana, laguntzak ukatzeak babesari dagokionez dakartzan mugak, kontrol-funtzioa hazi izana eta esku-hartze sakonetarako baliabiderik eza, esate baterako. Gauza bera gertatzen da akonpainamenduarekin ere, hau da, hura martxan jartzeko oztopo nabarmenak egoten direla sarri, teknika horrek denbora eta lan handia eskatzen baititu. Horretaz gain, austeritatepolitikek ere zeresana izan dute gizarte-politiketan eta, honenbestez, baita gizarte-zerbitzuetan ere. Hori horrela, azken urteetan, joera asistentzialistak modu progresiboan hazi dira.

Hori gutxi balitz bezala, gizarte-zerbitzuetako profesionalek diotenez, politika neoliberalek birfamiliarizazioa ekarri dute, neoasistentzialismo esaten diotena, eta, hala, arretaren gaineko ardura erakunde publikoetatik familiara eta hirugarren sektorera edo, zehatzago esateko, ongintzaentitateetara igaro da. Adituen arabera, horrek guztiak ongintzara itzularazten gaitu berriro, baliabideen gestio mekanikoa hazi eta esku-hartze soziala gutxitu egiten delako. Inbertsioez mintzatu garenean aipatu dugun bezala, zuzeneko baliabide eta zerbitzuak murrizten ari dira poliki-poliki, eta, haien ordez, beharrizanak asetzeari dagokionez, gero eta protagonismo handiagoa hartzen ari dira antolakunde karitatetsu eta filantropikoak, eta horrek unibertsaltasunetik urruntzen eta praktika asistentzialistetara hurbiltzen gaitu. Horren guztiaren ondorioz, pertsona txiroak sistemaren mendeko bihurtzen dira, haiei eskaini behar izaten zaielako arreta gehien, eta horrek kalte egiten dio hain beharrezkoa den sistemaren legitimazioari. Hala ere, bada ongintzaren balio horiek babestu nahi edo nostalgiaz hartzen dituenik ere, ongia egitearen bertutea, gizadiarenganako maitasuna edo sufritzen dutenenganako elkartasuna garrantzizkoak direlakoedo (Hernández-Echegaray, 2019).

Labur esanda, beraz, elementu korapilatsuen arteko elkarreragina argia dela esan eta batak bestearengan eragina duela azpimarratuko dugu. Objektuaren zehaztasun ezak oztopatu egiten du unibertsaltasunaren moduko printzipio garrantzitsuak garatzea, eta horrek eragina du gizarte-zerbitzuetan eskaintzen den arreta-ereduan. Gizarte Zerbitzuen Euskal Sistemari dagokionez, oso arau-esparru garatuak baditugu ere, alde handia dago, gorago ere esan dugun bezala, esparru horien printzipioen eta haiek errealitatean gauzatzeko moduaren artean (Zalakain, 2019). Gizarte-zerbitzuen sistema asistentzial erresiduala atzean utzi eta sistema unibertsal modernora jauzi egin nahi izan da, baina, sistema hori arau-esparruetan behar bezala jaso bada ere, hura praktikan hedatzeko zailtasunak nabarmenak izan dira, hemen aipatu diren elementu korapilatsuen eraginez, besteak beste (Fustier, 2017).

\section{Korapiloak gizarte-langintzatik abiatuta aztertzen}

Gizarte-langintza behin baino gehiagotan nahastu izan da gizarte-zerbitzuekin, lanbideak pisu handia baitu sistemaren barruan (De Las Heras, 2019). Hala ere, gizarte-langintza diziplina akademikoa da diziplina aplikatua, alegia-, lanbide ere bai baita, eta, beraz, ezaugarri bereziak ditu. da -diziplina aplikatua, alegia-, lanbide ere bai baita, eta, beraz, ezaugarri bereziak ditu. Gizarte-langintzaren berariazko zeregina da esku-hartze sozialean jardutea, eta, hein handi batean, gizarte-zerbitzuen sistemaren barruan egiten du hori. Horrek garapen handia ekarri dio gizarte-langintzari, hazteko aukera eman baitio, baina aipatzekoa da harreman horrek diziplinaren eta lanbidearen arteko aldea areagotzea ere ekarri duela. Izan ere, gorago esan dugunez, eskuhartze soziala da gizarte-langintzaren zereginetako 
bat, eta ekarpen tekniko horixe da, zentzu hertsian, haren balio erantsia, hau da, akonpainamendua eta harreman profesionala, gizarte-langileak herritarrarekin lantzen duen harremana. Egungo gizarte-zerbitzuetan, ordea, esku-hartze sozialak barenean hartzen ditu, besteak beste, bai baliabideen kudeaketa eta bai irizpideen betetze-mailaren gaineko kontrola, eta horrek erraz samar distortsiona dezake gizarte-langileari esku-hartze sozialarekin lotuta dagokion berariazko zeregina, bai eta lanbidea bera ere. Honenbestez, gizarte-zerbitzuen gaur egungo praktikatik urruti gera badaiteke ere, gizartelangintza honela definitu izan da:

Gizarte-langintza lanbide bat da, gizartearen aldaketa eta garapena, gizarte-kohesioa eta pertsonen indartzea eta askatzea sustatzen dituen jardunbidean eta diziplina akademikoan oinarritzen dena. Justizia sozialaren, giza baliabideen, erantzukizun kolektiboaren eta aniztasunarekiko errespetuaren printzipioak ezinbestekoak dira gizarte langintzan. Gizartelangintzaren, gizarte-zientzien, humanitateen eta sorterriko ezagueren teoriak oinarri hartuta, gizarte-langintzak pertsonen eta egituren partehartzea sustatzen du, bizitzaren erronkei aurre egitea eta ongizatea areagotzea helburu hartuta. (Gizarte Langintzaren Nazioarteko Federazioa, 2014)

Definizioa ikusi ondoren, lehenengo elementu korapilatsuari helduko diogu, hau da, objektua definitzeko zailtasunari. Ezer azaldu baino lehen, aipatzekoa da gizarte-langintzaren bi ildoek -diziplinak eta lanbideak- objektu bera dutela, bai ikerketari dagokionez, bai esku-hartzeari dagokionez. Gizarte-langintzaren komunitatean, batez ere akademikoan, etengabeko kezka sortzen duen kontua da objektuaren definizio eza, eta ez da harritzekoa, epistemologia osoa eta geroko ekintzaesparrua baldintza ditzakeen elementua baita. Gaiari buruzko pentsamoldeen errepasoa eginez gero, jada Mary Richmond (1917) aitzindariak berak ere arestian aipatzen zuenez, gizarte-langintzaren objektua egoera bera da, bai beste pertsona batzuekin dituen harremanen eraginez sortzen dena, bai komunitateko gizarte-erakundeekin dituen harremanen eraginez sortzen dena. Beste autore batzuek gaineratzen dutenez norbanakoaren eta egoeraren arteko harremana da objektua, beharrizanen eta haiek eguneroko bizitzan duten garrantziaren artekoa, norbanakoen eta gizartearen arteko tentsio dialektikotik abiatuz betiere (Vázquez, 2009). Autoreok egoerari erreparatzen dioten arren, inguruneak eta subjektuak - hau da, norbanakoak, taldeak edo kolektiboak - elkarri eragitean hark bizi duen egoera omen da objektua beste zenbait autoreren iritziz. Beste batzuen ustez, ordea, azpimarra egituretan jarri behar da, baldintza sozial edo estrukturalak direlako, haien esanetan, ongizatea edo desberdintasunak dakartzatenak eta pertsonen edo komunitateen garapena bultzatzen edo oztopatzen dutenak. María José Aguilar Idañezek (2013), aldiz, zera dio: iritzi horiek guztiak ez direla kontraesankorrak, eta norberaren hautu teorikoaren arabera interpreta daitezkeela. Aditu horrek eredu ekologiko-sistemikoan oinarrituz proposatzen duenez, beharrizan eta arazo jakinak dituen subjektuak eta haren testuinguru sozialak elkarri eragiten dioten modua hartu beharko luke objektutzat gizarte-langintzak.

Autore horien guztien ikuskerak gorabehera, Zamanillok (2018) azpimarratzen duenez, objektua definitzeak berebiziko garrantzia du gure diziplinarako, konplexutasuna aintzat hartu behar baita. Guk aipatu dugunaren ildotik, Zamanillok dio objektua definitu beharra dagoela, objektuak, metodoak, teoriek, paradigmek eta fenomenoek ematen baitiote ikerketari kategoria analitiko egokiak hautatzeko ahala, eta, gero, horrek irekitzen baitio bidea esku-hartzerako baliagarri izango den sorkuntza teorikoari. Autorearen esanetan, baina, gizarte-langintzari dagokionez, kontua are konplexuagoa da, hartan elementu praktiko asko nahasten baitira, hala nola helburua, subjektua, eremu profesionala eta esku-hartze eremua, eta horrek, Zamanillok “preteoriko” deitzen dion ezagutza mota sortzea dakar. Diziplinak objektuaren aferaren inguruan egindako garapenean, hasiera batean, norbanakoa-egoera aukeraren gainean egin zen lan, funtzionalismo hutsetik elkarrekintzaren ideiara pasatuz. Ondoren, birkontzeptualizazioaren aldeko mugimenduaren eraginez, pertsona zapalduaren ideia lantzen hasi zen, nahiz eta oraindik objektuaren definizio batetik urruti egon. Geroago, gizarte-beharrizanak erabiltzen hasi ziren objektutzat, planifikazioaren ikuskerak eraginda, eta, geroago, abstrakziorako ahalegin bat eginez, gizartearazoaren inguruan hasi ziren lanean objektuaren definizioan. Azkenik, ahuleziak azpimarratzen dira, eta, aurreko guztietan bezala, norbanakoaren eta ingurunearen garapena aipatzen da objektuaren definizio-saiakera gisa, eta horrek eredu erresiduala bultzatzen duela esaten da.

Esandakoak esanda, diziplinan onartuena den objektuaren definizioa Zamanillo katedradunak gauzatu duela esango genuke, hura izan baita gizarte-alorrean objektuaren inguruan gehien ikertu duen pertsonetako bat. Haren esanetan, berak plazaratzen duena oraindik ere garapen-prozesuan dagoen proposamen kritiko bat da, eta diziplinak ikertu beharreko errealitate soziala mugatu nahi bati erantzuten dio, hots, gizarte-langintzaren objektu izan daitezkeen elementuak identifikatu nahi bati. Ezinegon psikosozial gisa definitzen du objektua, eta horrek zer hartzen du barnean: "norbanakoaren ezinegon psikosozialarekin erlazionatutako fenomeno guztiak, haien genesi sozio-estrukturalaren eta bizipen pertsonalen arabera ordenatuak" (1999: 29). Kontzeptu nagusiak argitze aldera, “ezinegon” hitza erabili izan du, psikosozial gisa. Kontzeptu hauek guztiek aldaketaren nahia adierazten dute, eta horrek egiten ditu interesgarri. Kontzeptu “psikosozialak”, aldiz, genesi estrukturaletik zein bizipen pertsonaletik edaten du, bi horiek osagarriak eta ezinbestekoak 
baitira autorearen aburuz. "Genesi estruktural" deritze zenbait motatako arazo psikosozialei, baldin eta norberaren autonomia, identitatea eta eboluzioa oztopatzen duten egoeretan pertsonaren garapenerako ezinbestekoak diren aukerak sortzeko gabeziatik eratorriak badira; aldiz, “bizipen pertsonal” deritzo zenbaitetan jasaten den ezinegonari, baldin eta pertsonaren harremanetan (familia-, lan-, komunitate- eta instituzio-

harremanetan) nahasmendua eragiten badu.

Bigarren elementu korapilatsuari heldu bezain pronto, konturatzen gara gizarte-langintzaren unibertsalizazioaren afera erabat baldintzatzen duela objektuaren definizioak. Objektua bada gure xedea definitzen duena edo gizarte-ekintzaren markoa adierazten duena, horrek esan nahi du objektua gutxi-asko unibertsalagoa izan daitekeela. Kasu honetan, unibertsaltasuna gizarte-langintzaren ekintza-eremuarekin lot dezakegu, hau da, profesionalizazio-prozesuarekin, lanbideak berak burutu duen garapenarekin.

Gizarte-langintza XIX. mende bukaeran sortu zen, pertsona txiroei beren oinarrizko beharrizanak asetzeko, asistentzia-ekintza gisa. Gizartelangintzaren hastapenak Elizaren karitateari lotuak daude, baina hasieran karitatea zenak filantropiari eman zion bidea geroago. Txiroei lagundu behar zitzaiela argi zegoen, baina hori modu ordenatuan egin behar zenez, filantropia -hots, karitatearen arrazionalizazioa- nagusitzen hasi zen. Industralizazioarekin batera, gizarte-arazo berriak eta desberdintasunak areagotzen hasi ziren eta, orduan, egoerei nolabait aurre egin behar zitzaiela eta, estatuak gizarte-laguntza antolatzeari ekin zion (Zabalo, 2008). Zenbait fase bereizten dira gizarte-langintzaren bilakaeran: fase preteknikoa, karitatearekin zerikusia duena; fase teknikoa gizartelaguntza antolatua martxan jartzen duena; fase prezientifikoa, ongizatearekin zerikusia duena eta gizarte-zerbitzuei lotuago dagoena, eta, azkenik, fase zientifikoa, gizarte-arazoak modu zientifikoan aztertu, diagnostikatu, erantzunak bilatu eta aurreikustean datzana (De la Red, 1993; Berasaluze, 2011).

Bilakaera horretan, interesgarria da ikustea nola garatu den gizarte-langintza asistentzia sozial gisa sortua izan zenetik gaur egunera arte. Izan ere, gizarte-langintzak bide luzea egin du arestian behartsuei edo oinarrizko beharrizanak ase ezin zituzten pertsonei modu ez profesionalean erantzuten zion jarduera gisa sortua izan zenetik, eta, hala, gaur egungo definizioekin bat etorriz, beharrizanetatik harago dagoen eta pertsonen askapena eta autonomia sustatzea helburu duen diziplina zientifiko eta lanbide bihurtu da. Hala ere, gaur egun ere bada gizarte-langintza marjinalitatearekin lotzen duenik. Agerikoa da eskubideen urratzeekin edo bazterketa-egoerekin lan egiten dugula. Argi dago, beraz, nork behar izaten duen gure laguntza profesionala: beharrizan sozialak dituztenek, mendekotasun-egoeran daudenek edo desabantaila sozialak dituztenek, alegia.
Hala ere, gure lanbidean lehentasuna ematen diegu behar bereziak dituzten pertsona eta kolektiboei, edota gabezia handiagoa dutenei eta gizarte-bazterketa egoeran daudenei. Adibidez, zein dira gure jardueren edo ikerketa-lanen xedeak, eta zer-nolako egoerei egiten zaie aurre? Lehenik, desabantaila sozialei edo gizarte-bazterketarekin lotutako hainbat egoerari: gabezia ekonomiko, afektibo, emozional eta politikoei, besteak beste; bigarrenik, diskriminazioarekin lotutako hainbat egoerari: generoarekin, estetikarekin, etnia edo kulturarekin, adinarekin, lanbidearekin, gaixotasunekin, bizitza-aukerekin edo aukera intelektual ideologikoekin lotutakoei, esate baterako; hirugarrenik, zenbait mendekotasun-egoerari, hala nola bizitza kudeatzeko autonomiarik ezari, aukerarik ezari eta arriskuei. Azken finean, giza eskubideak eta gizarte-eskubideak hausten diren edozein egoera du langai gizarte-langintzak, laguntza-harremanen eta lankidetza horizontalaren bidez pertsonen (subjektuen) gaitasunak eta autonomia sustatzea baita diziplina horren helburua.

Hori horrela, ikus daiteke gizarte-langintza oinarrizko beharrizanak ase ezin dituzten pertsonei laguntza antolatua ematea baino askoz gehiago dela, eta, hori dela eta, gizarte-langileon lana unibertsalizatu egin dela. Azken finean, unibertsala izateak herritar ororentzat irisgarri izatea dela aipatu badugu sarreran, orain argi eta garbi esango dugu, zerrendatu ditugun xedeei erreparatuz, edozein herritarrek izan dezakeela, orain edo gero, gizartelangilearen esku-hartze profesionalaren beharra, baita haren egoera ekonomikoa txarra ez bada ere. Hortaz, gizarte-langintza jarduera zientifiko bat da, gizarte-eraldaketa, gizarte-kohesioa eta justizia soziala sustatzen dituena.

Hirugarren eta azken elementu korapilatsua gizarte-langintzaren esku-hartzearen eredua da. Gizarte-langintza burokratizazioarekin eta, batez ere, asistentzialismoarekin lotzen da, eta horrek asko urruntzen du jarduera profesionalaz, diziplinaz eta lanbideaz eman dugun definiziotik. Gizartelangintzaren jatorria asistentzialista da, eta badirudi horren arrastoak bizirik jarraitzen duela oraindik ere gizartean eta gizarte-langileongan.

Herritarrekiko harremanetatik abiatuz martxan jartzen den esku-hartze soziala izatea, horixe da gizarte-langintzaren berariazko ezaugarria. Egun, banakako gizarte langintza erabiliz, kasuen zein baliabideen kudeaketari eskaintzen zaion denborak oztopatu egiten du gizarte-langintzari balio erantsia eta espezifikotasuna ematen dion esku-hartze sozial hori lantzea. Horrek joera asistentzialistetara eramaten gaitu berriro, eta, batzuetan aipatzen denez, gizarte-langileok “lan bigun” esaten zaienetara egokitu ote garen susmoa ere egon liteke; alegia, burokratizazioa sustatu eta baliabideak kudeatzen eta informazioa ematen baino aritzen ez ote garen. Horrek erabat desitxuratu du gure jarduera profesionala, baliabide eta zerbitzu hutsak ematera lerrarazi baikaitu, prebentzioa eta sustapena xede duten ekintzetan jardun ordez. 
Gizarte-langintzaren oinarrizko funtzioetako bat asistentzia da, eskubide sozialak eta baliabideak ezagutzen ditugun profesionalak baikara. Funtzio hori beharrezkoa da, batez ere krisi garaian. Hala ere, ezin da funtzio hori herritarren gizarte-eskubideen errekonozimendutik bereizi. Ondorioz, funtzio hori ez da asistentzialismoarekin nahasi behar, gure ekarpenaren amaierako xedea partaidetzaren bidez aldaketa-aukerak eraikitzea edo berreraikitzea baita, egoera pertsonalen eta kolektiboen hobekuntzan eta/edo eraldaketan eragina izan dezaten.

Halaber, zehaztu beharra dago asistentziafuntzioarekin batera bestelako funtzioak ere betetzen ditugula. 2001. urteaz geroztik, eta Kode Deontologikoan (2012) jasotakoaren arabera, hauek dira gizarte langilearen funtzioak: informazioa, ikerketa, prebentzioa, asistentzia, arreta zuzena, gizarte-sustapena eta gizarteratzea, bitartekaritza, plangintza, kudeaketa eta zuzendaritza, ebaluazioa, gainbegiratzea, irakaskuntza eta koordinazioa. Horrelaxe lortzen da, hain zuzen, gure jarduera profesionala prebentiboa izatea (zuzeneko arrazoiei edo arazo jakinei aurre egitea baita haren helburua), bai eta sustagarria (autonomia pertsonala, hezkuntza eta partaidetza sustatzen baititu), asistentziala (informazioa, orientazioa, aholkularitza eta laguntza ematen baititu) eta errehabilitatzailea (gizarteratzeprozesuak sustatzen baititu) ere. Nolanahi ere, herritarrekin ezartzen ditugun harremanak, neurri batean, "kasuaren kudeatzaile" edo "kasuaren arduradun" baten bitartekaritzaren pean geratzen dira, eta horrek herritarren "erantzukizunik eza eta pasibotasuna” eragiten harreman-lana galarazten du, pertsonak gizarte-zerbitzuetako erabiltzaile, paziente edo bezero bilakatzen dituenez gero. Horregatik da hain garrantzitsua pertsonen herritartasuna aldarrikatu eta sustatzea, eskubide eta betebeharren subjektu diren heinean.

Profesionala elkarrekintza saihesten duen burokratarekin edo baliabide-kudeatzailearekin lotzen duen irudia uxatu behar dugu, nahasmendua besterik ez dakarrelako eta lanbidearekin bat ez datorrelako. Berez, gizarte-langintza baliabide bat da bere horretan, eta prestazio ekonomikoak eta gainerako gizarte-baliabideak tresnak dira, gizartelangileak bere jardunean erabil ditzakeenak (edo ez). Inoiz ere ez dute, baina, gizarte-langilea bera ordezterik izango; izan ere, bere praxia bete ezean, gizarte-langilearen jarduna langile administratibo espezializatu batena izango litzateke, besterik ez.

Gizarte-langintzaren alorreko zuzeneko eskuhartzeetan pertsonekin ari garela, ezinbestekoa da entzuketa, enpatia eta laguntza lantzea eta pertsonen gertuko baliabideak aktibatzea, bai eta herritarren eskubideak betearazteko beharrezkoak diren baliabide publikoen eskasia edo gabezia ezagutaraztea eta salatzea ere (Fombuena, 2020). Profesionalen eta herritarren arteko lankidetza prozesu komunikatiboan datza, non elkarrizketa den erabiltzen den teknika nagusia. Teknika horren oinarrizko helburua gurekin batera lan egiten duten pertsonak gurekin arriska daitezen lortzea da, errealitatearen askotariko interpretazioak aurkitzeko dinamika eta prozesuetan parte hartuta, bestelako kontakizunak eta narrazioak eraikitzeko xedea duten aukerak eta ikuspuntuak zabalduta, aldaketarako alternatiba diren heinean. Horrek barnean hartzen ditu ondoez-egoerak eta desabantaila sozialak ahantzarazten edo eragiten dituzten egituren aldaketarantz zuzendutako ekintzak (Campos eta Cardona, 2019).

Hona hemen, beste askoren artean, gure lana deskribatzen duten alderdi nagusiak: gizartelangileak arreta zuzena ematen die pertsonei, prozesu osoan zehar laguntzen die aldaketarako alternatibak berreraikita; eskubide sozialen eta baliabideen inguruko informazioa, aholkularitza eta orientazioa eskaintzen dizkie, gure praxiaren xede diren egoerak beren osotasunean ebaluatzen ditu eta erantzun integral bat planteatzen du; partaidetzaren bidez aldaketarako aukerak diseinatu eta eraikitzen ditu, eta eraldaketaren xede diren egoerei erantzun pertsonala eta kolektiboa emateko prozesuetan laguntzen du. Gure funtzio garrantzitsuenetako bat hau da: gizarte-bidegabekeria sortzen duten eta pertsonei eragiten dieten egoeren azterketan eta salaketan laguntzea, egoera horiek gizarteproiektuen diseinuari esker prebenitu ahal izateko (Ovejas, Ariño, Berasaluze, 2018).

Laburbilduz, azken lerroetan deskribatu den gizarte-langintza errealitate bihurtuko balitz, horrek benetako unibertsalizazioa ekarriko lieke bai diziplinari eta bai lanbideari, eta, horri esker, oraindik ere indarrean dauden joera asistentzialistak baztertuko genituzke. Lehenengo lerroetan jasotako definizioa betetze aldera, jaso ditugun objektuen adierek berek marrazten eta irudikatzen dute egokien gizarte-langintzaren ekintza-eremu eta norabidea.

\section{Korapiloak askatzeko bidean}

Lan honen bizkarrezur diren elementu korapilatsuen azterketa paraleloa egitean ikusi dugun legez, bai gizarte-langintzak eta bai gizarte-zerbitzuek ere, bi-biek dute oinarrizko erronkei aurre egin beharra, hots, bakoitzaren objektua egoki definitu, mugatu, unibertsaltasunaren hautua gauzatu eta arretazein esku-hartze ereduak garatu beharra; jakinik, gainera, hiru elementuak estuki lotuak daudela eta elkarri eragiten diotela etengabe. Erronka horiek partekatzea izan da, neurri handi batean, elkarrekin nahastu eta identifikatu izanaren arrazoia, haien identitateaz zalantza egin eta zein den zein galdetzeraino.

Elementu horiek, berez, ez dira negatiboak, sistemaren eta diziplinaren oinarriak sendotzeko ezinbestekoak baizik. Hori gutxi ez, eta haien definiziorik eta zehaztapenik ezak korapiloak sortu eta efektu negatiboak eragiten ditu batekiko eta bestearekiko, eta bien arteko lehia ere areagotzen du. Horregatik da hain garrantzitsua haien 
lanketa bideratzea, lehia horrekin amaitu eta espezifikotasunak aukera bezala erabiltzeko.

Lanketa hori, gainera, objektuari dagokionez behintzat, nork bere aldetik egin beharra dauka, biak direlako desberdinak (aurrenekoa diziplina eta lanbide da aldi berean; bigarrena, berriz, babes-sistema). Bakoitzaren espezifikotasuna argi izanik, elkarlanean aurrera egin beharko genuke, unibertsaltasuna eta ereduaren garapena egingarri bihurtzeko. Azken finean, ongizatearen eta justizia sozialaren helburuak partekatzen baitituzte.

Beti azpimarratzen da gizarte-langintzak gizartezerbitzuen eraikuntzan izan duen protagonismoa. Gizarte-zerbitzuen sorreran eta hasierako hamarkadetan, gizarte langintzak eragin handia izan zuen, baina egun, gizarte-politiken testuinguruan, indarra galtzen ari da. Urteak aurrera joan ahala, lanbidearekin gertatu ez den bezala, diziplinak ekarpen urriak egin dizkio gizarte-zerbitzuen sistemari, sistemaren diseinuan legerekin lotutako alderdiek pisu handiagoa baitute - pisu handiegia, guk uste- alderdi tekniko eta zientifikoek baino.

Sarreran aipatu bezala, maiz ikusi izan dugu badagoela halako tentsio-lotura bat gizartezerbitzuen eta gizarte-langintzaren artean, eta ez dela erraza bien arteko muga non den zehaztea. Gure ustez, oraingoan ere berdin gertatzen da; izan ere, triangelu korapilatsua osatzen duten elementuak askatzeko ahaleginean, bien arteko lankidetza eta harreman osagarria sortu beharrean, batak besteari egotzi izan diote elementuak korapilatu izanaren ardura. Hala, Gizarte Zerbitzuen Euskal Sistemari ez zaio mesede egin, eta hura sendotzeko eta garatzeko lanak ere oztopatu dira, nahiz eta, gizarte-zerbitzuek eta gizarte-langintzak partekatzen dituzten ongizatea eta justizia soziala sustatzeari dagokionez, sistema hori erreminta garrantzitsua izan.

Gizarte Zerbitzuen Sistemaren sendotzea sustatzeko, ikerketaren defentsa egin beharra dago, ezagutzan inbertitu behar baita. Sistema sendotzeko, uste dugu gizarte-langintzaren diziplinak ekarpen interesgarriak egin ditzakeela, eta, gure aburuz, ezagutza zientifiko eta tekniko gehiago behar da horretarako. Gizartelangintzak bere jarduerak sistematizatu behar ditu, sistemaren garapenerako onuragarria izango den ezagutza zientifikoa sortu eta etengabeko berrikuntza eta hobekuntza gauzatu ahal izateko. Hala, gizarte-zerbitzuen sorreran gertatu zen bezala, gizarte-langintzaren ekarpenaren aldarrikapena egin gurako genuke; izan ere, gizarte langintzak eskuhartze profesionala eskaintzen die gizarte-zerbitzuei, eta, era berean, gizarte-zerbitzuek gizarte-langintza profesionalki garatzeko modua ematen dute, nahiz eta harreman horiei buruz gutxitan mintzatzen garen. 


\section{Erreferentzia bibliografikoak}

AGUILAR HENDRICKSON, M. (2014): Apuntes para un replanteamiento de los servicios sociales en España, saila: Documentos de Trabajo del VII Informe sobre Exclusión y Desarrollo Social en España, 2.12. zb., Madril, Fundación Foessa, «http://www.foessa2014. es/informe/uploaded/documentos trabajo/04112014034343_2219.pdf>.

- (2018): "Servicios Sociales comparados: entre la beneficencia y la inversión social", in DEL PINO, E. eta RUBIO, M. (koord.), Los Estados de Bienestar en la encrucijada, Madril, Tecnos, 389.-404. or.

AGUILAR IDÁÑEZ, M.J. (2013): Trabajo Social: concepto y metodología, Madril, Paraninfo; Gizarte Langintzako Kontseilu Orokorra.

ARENAS, M. (2016): “¿Usuarios o ciudadanos? Intervención y participación en las políticas y servicios sociales", Comunitania, 11. zb., 27.-43. or.

BERASALUZE, A. (2011): “Dependentzia eta autonomia Gizarte Langintzan: lehena, oraina eta geroa", in BERASALUZE, A. eta OVEJAS, C. (koord.), Gizarte Langintzako IV. Jardunaldia: Mendekotasunetik Harantz, Leioa, Euskal Herriko Unibertsitateko Argitalpen Zerbitzua, 29.-41. or.

CAMPOS, J.F. eta CARDONA, J. (2019): “Trabajo Social relacional: una visión colaborativa", in SOBREMONTE, E., eta RODRÍGUEZ BERRIO, A., El Trabajo Social en un mundo de transformación: ¿distintas realidades o nuevos relatos para la intervención?, Valentzia, Tirant to Blanch, 223.-270. or.

DE LA RED, N. (1993): Aproximaciones al Trabajo Social, Madril, Gizarte Langintzako Kontseilu Orokorra; Siglo XXI.
DE LAS HERAS, P. (2019): Trabajo Social y Servicios Sociales, Madril, Paraninfo; Gizarte Langintzako Kontseilu Orokorra.

FANTOVA, F. (2008): Sistemas públicos de servicios sociales: nuevos derechos, nuevas respuestas, Bilbo, saila: Cuadernos Deusto de Derechos Humanos, 49. zb., Bilbo, Deustuko Unibertsitatea.

- (2019): "Naturaleza y esencia de los servicios sociales del futuro: el objeto a proteger y promover", in PELEGRÍ, X. (koord.), El futur dels Serveis Sociales, Bartzelona, Fundació Apip-Acam, 23.-41. or.

- (2021): "Nuestros servicios sociales tras un año de pandemia", Fantova.net, otsailak 15, 〈http:// fantova.net $/ ? p=3263$ '.

FERNÁNDEZ GARCÍA, T.; DE LORENZO, R. eta VÁZQUEZ, 0. (2012): Diccionario de Trabajo Social, Madril, Alianza.

FONBUENA, J. (2020): “La acción profesional del Trabajo Social: situación actual y prospectiva", in FONBUENA, J. (koord.), El Trabajo Social y su acción profesional, Valentzia, Nau Llibres. 96.-132. or.

FUSTIER, N. (2017): “El objeto de los servicios sociales: entre la norma y la teoría", Nuriafustier.blogspot. com, apirilak 4, 〈https://nuriafustier.blogspot. com/2017/04/el-objeto-de-los-serviciossociales.html>.

GIZARTE LANGINTZAKO KONTSEILU OROKORRA (2012): Gizarte Langintzako Kode Deontologikoa, Madril, Gizarte Langintzako Kontseilu Orokorra.

GIZARTE LANGINTZAKO NAZIOARTEKO FEDERAZIOA (2014): "Definición global del trabajo social", Gizarte Langintzako Nazioarteko Federazioa, <https:// www.ifsw.org/what-is-social-work/global- 
definition-of-social-work/definicion-global-deltrabajo-social/s.

HERNÁNDEZ-ECHEGARAY, A. (2019): "Retos de los Servicios Sociales en España según la opinión experta en Trabajo Social", Alternativas. Cuadernos de Trabajo Social, 26. zb., 123.-150. or.

HUBER, M.; MAUCHER, M. eta SAK, B. (2006): Study on Social and Health Services of General Interest in the European Union, Viena, European Centre.

JARAÍZ, G. (2011): Intervención social, barrio y Servicios Sociales Comunitarios, Madril, Fundación Foessa.

MARTÍNEZ VIRTO, L. eta PÉREZ ERANSUS, B. (2018): “El modelo de atención primaria de Servicios Sociales a debate: dilemas y reflexiones profesionales a partir del caso de Navarra", Cuadernos de Trabajo Social, 31. zb., 333.-343. or.

OVEJAS, C.; ARIÑO, M. eta BERASALUZE, A. (2018): "Tópicos y claves para comprender el Trabajo Social”, in RAYA, E.; CAPARRÓS, N.; LORENTE, B. eta ANAUT, S. (koord.), Ciencia y esencia en la práctica del Trabajo Social, Valentzia, Tirant lo Blanc, 297.-312. or.

RICHMOND, M.-E. (1917): Social Diagnosis, New York, Russell Sage Foundation.

SANTOS, J. (2012): El cuarto pilar. Un nuevo relato para los Servicios Sociales, Paraninfo, Madril.

SIIS CENTRO DE DOCUMENTACIÓN Y ESTUDIOS (2019): "Revisión de tendencias, innovaciones y buenas prácticas en el ámbito de los servicios sociales", Zerbitzuan, 70. zb., 5.-31. or, 〈https://doi.org/10.5569/1134-7147.70.01〉.

URIBE, Joan (2019): “Rellenando espacios: hacia una ordenación de los sistemas de servicios sociales desde la respuesta a la complejidad", Zerbitzuan, 68. zb., 75.-88. or., 〈https://doi. org/10.5569/1134-7147.68.06>.

VÁZQUEZ, O. (2009): “Naturaleza, fundamentos, conceto, principios, objetivos, objeto y sujetos del Trabajo Social", in FERNÁNDEZ GARCÍA, T. (koord.), Fundamentos del Trabajo Social, Madril, Alianza, 133.-160. or.

VISCARRET, J.J. (2009): Modelos y métodos de intervención en Trabajo Social, Madril, Alianza.

ZABALO, J. (2008): Gizarte Langintzarako Sarrera, Leioa, Euskal Herriko Unibertsitateko Argitalpen Zerbitzua.

ZALAKAIN, J. (2018): “¿Cómo blindar los Servicios Sociales? Invertir en conocimiento", Blog_SIIS.net, abendua, <https://blog.siis.net/2018/12/ como-blindar-los-servicios-sociales/ $>$.

- (2019): “Desigualdad, exclusión y cuidados en los territorios de Euskal Herria: retos, fortalezas, consensos, disensos y posibilidades de avance", in EUSKO IKASKUNTZA (ed.), Eusko Ikaskuntzaren XVIII. Kongresua: Geroa ElkarEkin, Eusko Ikaskuntza, Donostia,. 465.-480. or.

ZAMANILLO, T. (1999): “Apuntes sobre el objeto en Trabajo Social”, Cuadernos de Trabajo Social, 12. zb., 13.-32. or.

- (2018): Epistemología del Trabajo Social. De la evidencia empírica a la exigencia teórica, Madril, Ediciones Complutense.

ZAMANILLO, T. eta NOGUÉS, L. (2020): “Carta abierta a profesionales u políticos de los Servicios Sociales en tiempos de la Pandemia del Covid-19”, Asociación Foro SERVSOCIAL Madril, 〈https://4f8bb68a-edgb-44a6-bdf236b119do5fbb.filesusr.com/ugd/8fodee a983cezedd584dc2a32157ef5ecaod38.pdf . 